\title{
Russet of Apple Fruit Caused by Aureobasidium pullulans and Rhodotorula glutinis
}

\author{
M. C. Matteson Heidenreich, M. R. Corral-Garcia, E. A. Momol, and T. J. Burr, Department of Plant Pathol- \\ ogy, Cornell University, New York State Agricultural Experiment Station, Geneva 14456
}

\begin{abstract}
Matteson Heidenreich, M. C., Corral-Garcia, M. R., Momol, E. A., and Burr, T. J. 1997. Russet of apple fruit caused by Aureobasidium pullulans and Rhodotorula glutinis. Plant Dis. 81:337342.

Russet on apple fruits was caused by inoculation with isolates of Aureobasidium pullulans and Rhodotorula glutinis but not with Metschnikowia pulcherrima or two other unidentified yeasts, YT2 and YT17. Another unidentified yeast, YT5, caused russet in 1 of 2 years. Epiphytic survival of isolates on fruit was measured 3 months after inoculation. All isolates that caused russet survived epiphytically on fruit at harvest. With the exception of M. pulcherrima, nonrusseting isolates were not detected on the fruit at harvest. Conidia, hyphae, and chlamydospores characteristic of A. pullulans were observed in naturally russeted tissues of 14 different apple cultivars and Bartlett and Bosc pear collected from 13 orchards in New York state. A. pullulans was the most commonly isolated microorganism, and all A. pullulans isolates caused apple russet but varied in the severity of russet they caused. Isolates were identified using standard identification schemes. In addition, A. pullulans isolates were compared by generating fingerprints of restriction fragments of a PCR-amplified region of ribosomal DNA consisting of ITS-1, the 5.8S gene, and ITS-2.
\end{abstract}

Russet on apple, Malus $\times$ domestica Borkh., and other fruits results in lowered fruit quality and substantial economic losses to growers $(10,27)$. Thorough reviews have been written on the etiology of fruit russet $(13,35)$. Factors associated with apple russet include infection by the powdery mildew pathogen (Podosphaera leucotricha (Ellis \& Everh.) E.S. Salmon) $(39,40)$, insects $(11)$, cultural and environmental factors $(8,27,38)$, mechanical injuries (35), and pesticides $(20,30,35)$. Pear fruit russet was also recently shown to be caused by indoleacetic acid (IAA)-producing strains of bacteria $(6,22)$. The use of some fungicides $(9,13,35)$, gibberellic acid $(14,15,24)$, silicon dioxides $(12,26)$, and antagonistic bacteria (23) was shown to reduce the incidence of apple russet. Microscopic observation of russeted areas of fruit shows breaks in the cuticular layer with underlying layers of dead epidermal cells $(1,29)$. Fruit cultivars differ greatly in their susceptibility to russet (10).

In this paper, we demonstrated that the yeast Rhodotorula glutinis (Fresen.) F.C. Harrison, the hyphomycete Aureobasidium pullulans (de Bary) G. Arnaud, and one other unidentified yeast can cause russet of apple. We also investigated the relative

Corresponding author: T. J. Burr
E-mail: tjb1@ cornell.edu

Accepted for publication 27 January 1997.

Publication no. D-1997-0225-05R

(C) 1997 The American Phytopathological Society abilities of these and other yeast isolates to survive epiphytically on apple fruit. In addition, we observed $A$. pullulans sporulating in naturally russeted fruit tissue of several apple and pear cultivars, and we isolated the fungus from them.

\section{MATERIALS AND METHODS}

Sources and identification of isolates. A. pullulans isolates ATCC 90393, ATCC 11942, and ATCC 12536, Cladosporium cladosporioides (Fresen.) G.A. De Vries isolate NRRL 20632, and Hormonema dematioides (Lagerb. \& Merlin) isolate CBS 11629 were kindly provided by John $\mathrm{H}$. Andrews (University of Wisconsin, Madison).

We collected additional fungal isolates from three sources, including surface washes from apple fruits and leaves, russeted areas on apple and pear fruits, and as contaminants growing on agar plates with conidial germlings of Venturia inaequalis (Cooke) G. Wint. The conidia (used in a fungicide resistance study) were collected from scab lesions on apple cv. Cortland trees and were germinated on potato dextrose agar (PDA) (Difco, Detroit, MI) containing $50 \mu \mathrm{g} /$ liter each of streptomycin sulfate, chloramphenicol, and tetracycline (PDA Plus). Isolations from leaves and fruit were done by submersing the tissues with an appropriate amount of $0.05 \mathrm{M}$ phosphate buffer, $\mathrm{pH} 6.5$, in plastic zipper bags and then sonicating them in a Bransonic ultra sonicator (Fisher Scientific, Springfield, MA) for $10 \mathrm{~min}$. Isolations from russeted sections of fruit were done by collecting tissue with a scalpel (about
$10 \mathrm{~mm}^{2}$ ) from fruit and triturating in a drop of sterile distilled water on a glass slide. All isolations were done by plating sonicates and tissue triturates on PDA Plus and incubating them at $23 \pm 1^{\circ} \mathrm{C}$ for $48 \mathrm{~h}$.

R. glutinis isolate 79B and Metschnikowia pulcherrima (P.I. Pitt \& M.W. Miller) isolate $115 \mathrm{~B}$ were identified according to the methods of Kreger-van Rij (21) and Barnett et al. (2). Briefly, this involved determining the ability of the isolates to utilize 44 carbon and 9 nitrogen sources, determining their nutritional requirement for 10 vitamins, growth at five temperatures $\left(25\right.$ to $\left.40^{\circ} \mathrm{C}\right)$, growth in different osmoticum, resistance to cycloheximide, fermentation ability, starch formation, acetic acid production, urea hydrolysis, and Diazonium Blue B reaction. Observations were made of type of vegetative reproduction and size and shape of vegetative cells in malt extract (Difco) and yeast-glucosepeptone broths (2). Colony morphology and hyphal and conidial characteristics were observed on malt extract agar (Difco) and 2\% glucose-yeast-peptone agar (2). Ballistospore discharge was done on corn meal agar (Difco). Yeasts were also grown on ascosporulation media, including V8 agar, Gorodkowa agar, malt-yeast-peptone-glucose agar, and malt extract agar, according to the methods of Barnett et al. (2).

We identified isolates of $A$. pullulans according to taxonomic descriptions $(2,7,16,21)$ and by ribo-fingerprinting. Ribo-fingerprinting analysis was previously used effectively for identification of fungi and bacteria $(17,34)$. Identification of A. pullulans was also confirmed by C. K. J. Wang at SUNY College of Environmental Science and Forestry, Syracuse, New York. All isolates were maintained on PDA and stored at $-80^{\circ} \mathrm{C}$ in cryogenic storage medium (5).

Isolating A. pullulans genomic DNA. Cultures were grown in potato dextrose broth (Difco) overnight. The mycelial growth was washed twice with $2 \mathrm{ml}$ of sterile distilled water by centrifugation for $2 \mathrm{~min}$ at $1,000 \times g$. After centrifugation, the precipitate was mixed with extraction buffer $(10 \mathrm{mM}$ Tris- $\mathrm{HCl}$ buffer, $2 \mathrm{mM}$ EDTA, $100 \mathrm{mM} \mathrm{NaCl}$, and $2 \%$ sodium dodecyl sulfate). The mixture was frozen at $-80^{\circ} \mathrm{C}$ for $2 \mathrm{~h}$ and thawed at $70^{\circ} \mathrm{C}$ for $10 \mathrm{~min}$. An equal volume of a phenol-chloroform mixture (1:1) was added, mixed by inverting the tube, and 
centrifuged for $5 \mathrm{~min}$ at $1,000 \times g$. The extraction was performed twice with a subsequent chloroform-isoamyl alcohol (24:1) extraction. The final aqueous

phase was precipitated with 2 volumes of ethanol and $3 \mathrm{M}$ sodium acetate $(\mathrm{pH}$ 5.0). The resulting pellet was washed with $70 \%$ ethanol, dried at room tem-

Table 1. Identity or description and origin of Aureobasidium pullulans and yeast isolates used to inoculate apple fruit

\begin{tabular}{lcl}
\hline Identity or morphology type $^{\mathbf{y}}$ & Isolate & Origin $^{\mathbf{z}}$ \\
\hline Aureobasidium pullulans & YT16 & Cortland lvs, C \\
A. pullulans & YT42 & Bosc pear \\
A. pullulans & YT145 & Mutsu \\
A. pullulans & YT146 & Golden Russet \\
A. pullulans & YT151 & Golden Delicious \\
A. pullulans & YT152 & Rome \\
A. pullulans & YT154 & Crab apple \\
A. pullulans & YT156 & Idared \\
Metschnikowia pulcherrima & $115 \mathrm{~B}$ & McIntosh lvs, B \\
Rhodotorula glutinis & 79B & McIntosh lvs, C \\
White, shiny, oval, bipolar & YT17 & Cortland lvs, C \\
Salmon, oval, bipolar & YT2 & McIntosh lvs, A \\
Dark salmon, oval, bipolar & YT5 & Golden Delicious fr, B \\
\hline
\end{tabular}

${ }^{y}$ Isolates were identified as described in text. Unidentified yeasts are categorized by colony color on potato dextrose agar (PDA), yeast cell shape, and budding type.

${ }^{z} \mathrm{~A}, \mathrm{~B}$, and $\mathrm{C}$ represent different orchards in Geneva, New York; all other isolates collected from naturally russeted areas on fruit were collected from different orchards in New York. All isolations from orchard $\mathrm{C}$ were from germinated conidia of Venturia inaequalis that were growing on PDA plus streptomycin sulfate, chloramphenicol, and tetracycline. Lvs $=$ isolates from leaves, $\mathrm{fr}=$ isolates from fruit.
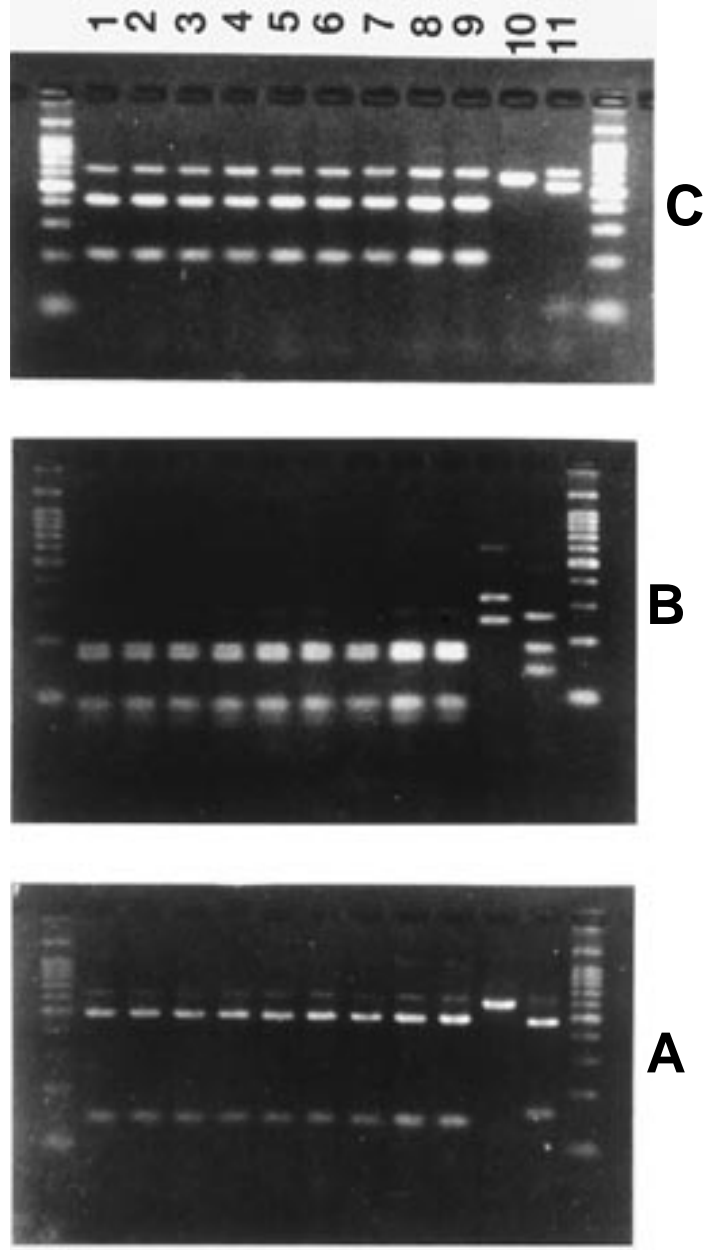

Fig. 1. Restriction patterns of the polymerase chain reaction (PCR)-amplified ribosomal DNA region that includes intergenic spacer region ITS- 1 plus the $5.8 \mathrm{~S}$ gene and ITS-2, which were digested with (A) RsaI, (B) CfoI, and (C) AluI. First and last lanes = DNA size markers; lanes 1 through $6=$ Aureobasidium pullulans isolates (YT16, YT142, YT145, YT146, YT151, and YT154); lanes 7 through 9 $=$ A. pullulans isolates ATCC 90393, ATCC 12536, and ATCC 11942; 10 = Cladosporium cladosporioides isolate NRRL 20632; and 11 = Hormonema dematioides isolate CBS 11629. perature, and dissolved in sterile distilled water.

Amplification and ribo-fingerprinting. A region of chromosomal DNA that is known to be variable between species was amplified. This is a ribosomal DNA region that includes intergenic spacer region (ITS)-1 plus the $5.8 \mathrm{~S}$ gene and ITS-2. It was amplified using the primers ITS4 $\left(5^{\prime}\right.$ TCCTCCGCTTATTTGATATGC-3'), and ITS5 (5'-GGAAGTAAAAGTCGTAACAAGG-3') (37). PCR was performed with a total volume of the reaction mixture containing $0.1 \mu \mathrm{g}$ of DNA, $2.5 \mathrm{mM} \mathrm{MgCl} 2,50$ $\mu \mathrm{M}$ of each primer, $0.1 \mathrm{mM}$ (each) deoxynucleoside triphosphate (dNTP), $2.5 \mathrm{U}$ Taq Polymerase (Promega, Madison, WI), reaction buffer $(10 \mathrm{mM}$ Tris-Cl, $50 \mathrm{mM}$ $\mathrm{KCl}$ and $0.1 \%$ Triton $\mathrm{X}-100$ ) under 3 drops of mineral oil. Amplification was performed in a PTC-100 Programmable Thermal Controller (MJ Research, Inc., San Francisco, CA) programmed for one cycle of $3 \mathrm{~min}$ at $94^{\circ} \mathrm{C}, 35$ cycles of $1 \mathrm{~min}$ at $94^{\circ} \mathrm{C}, 1 \mathrm{~min}$ at $52^{\circ} \mathrm{C}$, and $2 \mathrm{~min}$ at $72^{\circ} \mathrm{C}$, and final extension for $7 \mathrm{~min}$ at $72^{\circ} \mathrm{C}$. Amplification products were purified using Millipore regenerated cellulose columns (Millipore Corp., Bedford, MA). Amplicons were digested with RsaI, CfoI, HaeIII, AluI, and TaqI (Promega), and digests were analyzed by $3 \%$ agarose gel electrophoresis in TBE buffer. Gels were stained with $0.5 \mu \mathrm{g}$ of $\mathrm{EtBr}$ per $\mathrm{ml}$ and photographed using a UV transilluminator.

Fruit inoculation. Isolates were grown on PDA for $48 \mathrm{~h}$ at $23 \pm 1{ }^{\circ} \mathrm{C}$ (Table 1). For fruit inoculation experiments in 1994 and 1995, growth was harvested with rubber spatulas and suspended in 20 liters of 0.05 $\mathrm{M}$ phosphate buffer, $\mathrm{pH}$ 6.5. Suspensions were adjusted to an optical density (OD) of 1.0 at $600 \mathrm{~nm}$ using a Spectronic $20 \mathrm{spec}-$ trophotometer (Bausch and Lomb, Rochester, NY) corresponding to approximately $1 \times 10^{8} \mathrm{CFU} / \mathrm{ml}$ for isolates 79B and YT2, and $1 \times 10^{7} \mathrm{CFU} / \mathrm{ml}$ for $115 \mathrm{~B}$, YT5, YT17, and the A. pullulans isolates. Suspensions of microorganisms were applied to fruit with a Flo-Master Pro sprayer (R.L. Flowmaster Corp., Lowell, MA) pressurized to 40 psi with argon gas. In all experiments, fruit clusters and surrounding leaves were sprayed to drip point.

Each microorganism was applied to 25 fruit clusters on each of three to four branches of a single McIntosh apple tree. Suspensions of isolate 79B and 115B were applied to three trees (one tree per block) in a randomized complete block design within an orchard at the Geneva Experiment Station. Microorganisms were applied weekly beginning when trees were in the green-tip phenological development stage. Applications of the microorganisms were made five times in 1994 and seven times in 1995.

In a second experiment in 1995, isolates YT2, YT5, YT16, YT17, 79B, and 115B were tested for their ability to russet 
McIntosh apple. The isolates were grown as previously described and mixed to the same concentration in a final volume of 1 liter. Applications were made using plastic spray bottles. Inoculations were made to 25 fruit clusters on a single branch of McIntosh apple trees and were replicated on three trees in a randomized complete block design in an orchard at the Geneva Experiment Station. Six inoculations were made at weekly intervals beginning at the green-tip phenological stage.

In 1996, the same experiment was repeated using isolates YT2, YT5, YT16, YT17, and seven additional A. pullulans isolated from naturally russeted fruit: YT142, YT145, YT146, YT151, YT152, YT154, and YT156. Isolates were grown as previously described and mixed to the same concentration in a final volume of 2 liters and applied in the same manner to 25 fruit clusters each, located on four individual branches of a single McIntosh apple tree, for a total of 100 clusters. Distilled water was used as a control in place of phosphate buffer to eliminate russet caused by the buffer alone. Six inoculations were made at weekly intervals beginning at the green-tip phenological stage and ending 3 weeks after petal fall.

Data were taken when russet was first observed in June of each year and again when fruit were harvested in mid-September. Fruit were rated on a scale of 0 to 4 based on an approximation of the area of fruit surface with russet. A numerical rating of 0 ( 0 to $3 \%$ of the fruit surface having russet), 1 (4 to $20 \%$ russet), 2 (21 to $45 \%$ russet), 3 (46 to $74 \%$ russet), or 4 (greater than $75 \%$ russet) was given to each fruit. The percent russet severity was calculated as: $\left[\sum\right.$ (rating $\times$ the number of fruit with the rating) $/ 4 \times$ total number of fruit] $\times 100$. Values were analyzed statistically using the SAS General Linear Models $t$ test (28).

Epiphytic populations on fruit. For the 1994 and 1995 inoculation experiments, nine apple fruit were collected randomly from each inoculated tree at harvest. They were weighed and placed individually in plastic zipper bags to which $100 \mathrm{ml}$ of 0.05 $\mathrm{M}$ phosphate buffer was added and then sonicated in the ultrasonic cleaner for 10 min. Serial dilutions of sonicates in buffer were plated on PDA and incubated at $23 \pm$ $1^{\circ} \mathrm{C}$ for $48 \mathrm{~h}$. Colonies were counted, and populations were calculated as $\mathrm{CFU} / \mathrm{g}$ of tissue.

In the 1996 experiment, populations were measured in a different manner in order to more closely quantify epiphytic populations on a given fruit surface area. A 2-mm cork borer was used to cut disks from fruit, which were placed individually into sterile 2.0-ml Eppendorf tubes containing $1.5 \mathrm{ml}$ of distilled water. Tubes were submersed in the ultrasonic cleaner and sonicated for $10 \mathrm{~min}$. Serial dilutions of sonicates in water were plated on PDA
Plus and incubated at $23 \pm 1{ }^{\circ} \mathrm{C}$ for $48 \mathrm{~h}$. Colonies were counted, and populations were calculated as $\mathrm{CFU} / \mathrm{mm}^{2}$ of tissue.

Colonies of the inoculated isolates were identified on PDA Plus by previous morphological descriptions $(2,7,16,21)$. A. pullulans has white to cream, smooth, yeastlike colonies covered with slimy masses of conidia and mycelia becoming apparent at the colony margin; colonies often turn black with age. This darkening may occur over the entire colony except for the margin, or in lines or in regular or irregular sectors. $R$. glutinis has pink to red, smooth, round, shiny colonies; and $M$. pulcherrima has cream to reddish brown, smooth, round, dull colonies that are surrounded by a halo of red pigment (pulcherrimin), which is secreted into the medium. Counts of each colony type from inoculated fruits were compared at $48 \mathrm{~h}$ with counts of the same colony types from noninoculated fruits.

Isolations from naturally russeted fruit. Apple and pear fruit with russet were collected in September and October 1995 and June, July, August, and September 1996. Cultivars Mutsu, Golden Delicious, Golden Delicious "Smoothe", Golden Russet, Rome, Ida Red, Empire, Fuji, Stay- man, Cortland, McIntosh, Jonamac, Jonagold, and a crab apple, Malus sylvestris Mill., were collected from 14 orchards in western New York State. Bosc pear, Pyrus communis L. cv. Bosc, was also sampled from five orchards; Bartlett pear, P. communis cv. Bartlett, was sampled from one orchard. Hand sections of russeted tissues were first observed with a light microscope for the presence of fungal structures. To isolate fungi, tissue sections were triturated in sterile distilled water and streaked on PDA Plus. Plates were incubated at $23 \pm$ $1^{\circ} \mathrm{C}$ for $48 \mathrm{~h}$, and isolated colonies were restreaked on PDA.

\section{RESULTS}

Isolate identification. Sixty-eight fungal isolates were recovered from apple, including A. pullulans (19 isolates), $R$. glutinis (16 isolates), M. pulcherrima (7 isolates), and 14 distinct groups of yeasts based on colony type on PDA, cell shape, and budding type. A. pullulans was the predominant microorganism isolated from russeted fruit tissues of both apple and pear. Representative isolates from each identified microorganism and two isolates of unidentified yeasts were selected for pathogenicity tests.

Table 2. Russet severity and epiphytic survival of isolates of Rhodotorula glutinis and Metschnikowia pulcherrima in 1994 and 1995

\begin{tabular}{|c|c|c|c|c|}
\hline \multirow[b]{2}{*}{ Fungus, isolate } & \multicolumn{2}{|r|}{1994} & \multicolumn{2}{|c|}{1995} \\
\hline & Russet $(\%)^{y}$ & Population $(\mathrm{CFU} / \mathrm{g})^{\mathrm{z}}$ & Russet (\%) & Population (CFU/g) \\
\hline Control, buffer & $2.50 \mathrm{~b}$ & $\begin{array}{l}2.46 \times 10^{2}(79 \mathrm{~B}) \\
1.78 \times 10^{1}(115 \mathrm{~B})\end{array}$ & $6.67 \mathrm{~b}$ & $\begin{array}{l}1.81 \times 10^{1}(79 \mathrm{~B}) \\
1.52 \times 10^{0}(115 \mathrm{~B})\end{array}$ \\
\hline R. glutinis, 79B & $64.44 \mathrm{a}$ & $2.76 \times 10^{3}$ & $43.88 \mathrm{a}$ & $1.07 \times 10^{4}$ \\
\hline M. pulcherrima, 115B & $3.61 \mathrm{~b}$ & $2.67 \times 10^{3}$ & $11.67 \mathrm{~b}$ & $1.12 \times 10^{2}$ \\
\hline
\end{tabular}

${ }^{y}$ Percent russet severity was determined as described in text. Values in same column followed by different letters differ significantly at $P=0.05$ according to the SAS General Linear Models $t$ test; $\mathrm{LSD}=27.73$ and 10.53 , respectively.

${ }^{\mathrm{z}}$ Populations were determined in mid-September each year.

Table 3. Russet severity and epiphytic survival on fruit of Rhodotorula glutinis, Metschnikowia pulcherrima, and Aureobasidium pullulans isolates and two unidentified yeasts in 1995 and 1996

\begin{tabular}{|c|c|c|c|c|}
\hline \multirow[b]{2}{*}{ Isolate } & \multicolumn{2}{|c|}{1995} & \multicolumn{2}{|r|}{1996} \\
\hline & $\begin{array}{l}\text { Russet } \\
(\%)^{\mathrm{y}}\end{array}$ & $\begin{array}{l}\text { Population } \\
{\text { (CFU/g })^{\mathrm{z}}}^{\text {(C) }}\end{array}$ & $\begin{array}{l}\text { Russet } \\
(\%)\end{array}$ & $\begin{array}{l}\text { Population } \\
(\text { CFU/mm²) }\end{array}$ \\
\hline Control, buffer & $2.50 \mathrm{~d}$ & & & \\
\hline Control, water & $3.33 \mathrm{~d}$ & $\begin{array}{c}0.00 \times 10^{0} \\
\text { (all strains) }\end{array}$ & $0.00 \mathrm{~d}$ & $\begin{array}{l}1.70 \times 10^{-1}(\text { A. pullulans }) \\
0.00 \times 10^{0}(\text { all others })\end{array}$ \\
\hline 79B & $36.67 \mathrm{~b}$ & $1.87 \times 10^{3}$ & $\ldots$ & $\ldots$ \\
\hline 115B & $6.67 \mathrm{~cd}$ & $0.00 \times 10^{0}$ & & \\
\hline YT2 & $17.50 \mathrm{~cd}$ & $0.00 \times 10^{0}$ & $0.00 \mathrm{e}$ & $0.00 \times 10^{0}$ \\
\hline YT5 & $23.33 \mathrm{bc}$ & $8.47 \times 10^{1}$ & $7.10 \mathrm{e}$ & $0.00 \times 10^{0}$ \\
\hline YT16 & $80.83 \mathrm{a}$ & $1.46 \times 10^{3}$ & $52.90 \mathrm{abc}$ & $9.94 \times 10^{0}$ \\
\hline YT17 & $16.67 \mathrm{~cd}$ & $0.00 \times 10^{0}$ & $1.25 \mathrm{e}$ & $0.00 \times 10^{0}$ \\
\hline YT142 & $\ldots$ & $\ldots$ & $63.33 \mathrm{a}$ & $4.08 \times 10^{0}$ \\
\hline YT145 & $\ldots$ & $\ldots$ & $37.10 \mathrm{~d}$ & $1.27 \times 10^{0}$ \\
\hline YT146 & $\ldots$ & $\ldots$ & $56.68 \mathrm{ab}$ & $1.70 \times 10^{-1}$ \\
\hline YT151 & $\ldots$ & $\ldots$ & $50.40 \mathrm{abcd}$ & $2.38 \times 10^{0}$ \\
\hline YT152 & $\ldots$ & $\ldots$ & $45.40 \mathrm{bcd}$ & $8.84 \times 10^{-1}$ \\
\hline YT154 & $\ldots$ & $\ldots$ & $44.58 \mathrm{bcd}$ & $1.02 \times 10^{0}$ \\
\hline YT156 & $\ldots$ & $\ldots$ & $39.18 \mathrm{~cd}$ & $5.10 \times 10^{-1}$ \\
\hline
\end{tabular}

${ }^{y}$ Percent russet severity was determined as described in text. Values in same column followed by different letters differ significantly at $P=0.05$ according to the SAS General Linear Models $t$ test; $\mathrm{LSD}=18.35$ and 8.86 , respectively.

${ }^{\mathrm{z}}$ Populations were determined using different sampling procedures in 1995 and 1996. 


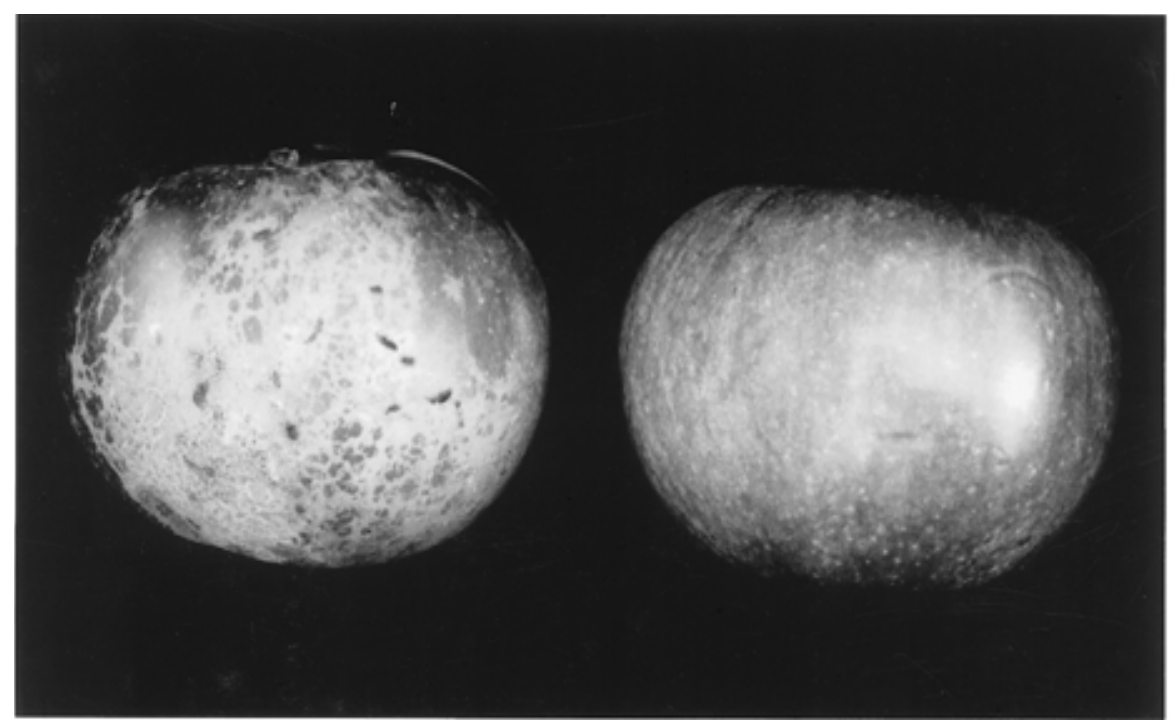

Fig. 2. Russet on McIntosh apple fruit inoculated with Aureobasidium pullulans isolate YT16 (left) compared with noninoculated fruit (right).

The ribo-fingerprinting patterns derived from digestion with $A l u \mathrm{I}, C f o \mathrm{I}$, and $R s a \mathrm{I}$ are shown in Figure 1. All A. pullulans isolates that were isolated in this study had fingerprints that were identical to authenticated isolates and could be differentiated from isolates of $C$. cladosporioides and $H$. dematioides. Digestions with TaqI and HaeIII also yielded no differences between A. pullulans isolates, and isolates could be differentiated from the other fungi (data not shown).

Fruit russet. In both 1994 and 1995, isolate 79B caused fruit russet, whereas 115B did not, and symptoms were more severe in 1994 than in 1995 (Table 2). Russet first appeared in June of both years as small, irregularly shaped corky areas on the fruit that developed into larger areas as the fruit matured, sometimes covering more than half of the fruit surface. Isolate 79B was detected from the fruit surface at harvest (13 weeks after the last inoculation) in 1994 and 1995 at average populations of $1.46 \times 10^{3}$ and $1.07 \times 10^{4} \mathrm{CFU} / \mathrm{g}$, respectively, whereas isolate $115 \mathrm{~B}$ was present at $2.67 \times 10^{3}$ and $1.12 \times 10^{2}$ $\mathrm{CFU} / \mathrm{g}$, respectively.

In the second 1995 experiment, isolates 79B, YT16, and YT5 caused significantly higher levels of russet than did YT17, YT2, 115B, the buffer, or nontreated controls (Table 3). Isolate YT16 caused extremely severe russet, resulting in the entire fruit surface being russeted in some cases (Fig. 2). Russet-causing isolates YT5, YT16, and 79B were detectable on fruit at harvest, while the nonrusseting isolates YT2, YT17, and 115B were not (Table 3).

In the 1996 experiment, isolates YT2, YT16, and YT17 responded in the same manner as in the previous year. YT5, however, which caused significant russet in 1995, caused no russet in 1996. The eight A. pullulans isolates all caused russet but differed significantly in russet severity. All isolates that caused russet on fruit were detectable on fruit surfaces at harvest; however, higher population levels did not correlate with increased russet severity (Table 3). Although leaves were inoculated at the same time as the fruit, no symptoms were produced by any of the isolates.

Isolations from naturally russeted fruit. Dark hyphae and arthrospores characteristic of A. pullulans (Fig. 3) were observed in sections of naturally russeted tissues of all apple (14 cultivars) and pear ( 2 cultivars) fruit that were collected from commercial orchards. Arthrospores were often found in close association with fruit hairs of both apple and pear (Fig. 3). A. pullulans was isolated from all of the russeted fruit sampled, and except for an occasional colony of other yeasts, no other microorganisms grew on PDA Plus. In 1996, we also examined apple fruit that were russeted as a result of sprays with different copper fungicides. In these cases, sporulation of $A$. pullulans was not evident, and the fungus was not isolated from the tissues (data not shown).

\section{DISCUSSION}

We identified A. pullulans, R. glutinis, and an unidentified yeast as potentially important causes of apple fruit russet. Isolates caused russet when inoculated on apple fruit, and A. pullulans was observed sporulating in russeted tissues of 14 apple cultivars and 2 pear cultivars collected from different regions of New York state. Because isolates of $A$. pullulans caused the most severe russet and because it was the most commonly detected microorganism on naturally russeted fruit, we believe that A. pullulans may be a major cause of apple and pear russet and may play a more significant role than the other russet-inducing fungi identified. Following inoculation, russet symptoms were usually severe, as in
Figure 2; however, varying russet patterns were observed on naturally affected fruits. Symptoms varied from a netted to a solid pattern covering primarily the light-exposed surfaces of the fruit and often surrounding the stem end.

More research is needed to identify the relative significance of these microorganisms in causing russet. Although A. pullulans has been recognized as a predominant epiphyte on apple $(18,19)$, we believe this is the first report identifying it as causing fruit russet. With the exception of P. leucotricha $(39,40)$ and IAA-producing bacteria on pear $(6,22)$, little attention has been given to microbial causes of fruit russet. It has been documented, however, that conditions known to favor russet, such as cool and wet conditions a few weeks after bloom $(27,32,35)$, are also generally favorable for microbial growth. In addition, it was previously shown that applications of certain fungicides can reduce the severity of russet $(35,36)$, implying that the fungicides may be affecting russet-inducing microorganisms.

It will be important to identify the environmental conditions and fruit developmental stages that affect the susceptibility of fruit to A. pullulans- and R. glutinisinduced russet. Previous reports indicate that fruit are susceptible to russet shortly after the petal-fall phenological stage of development. If such susceptibility periods can be identified for fungal-induced russet, it may be possible to suppress russet with fungicides or biological controls. In preliminary in vitro tests, we determined that $A$. pullulans and $R$. glutinis vary in their sensitivities to major groups of fungicides (4).

The unidentified yeast isolate YT5 caused significant russet on fruit in 1995 but not in 1996. Populations of YT5 were not detected on fruit prior to harvest in 1996, and therefore differences in environmental conditions may have affected its ability to survive and to cause russet.

The mechanism(s) by which $R$. glutinis and $A$. pullulans cause russet are unknown. Although all strains of $A$. pullulans that were used to inoculate apple caused russet, significant differences in the severity of the russet they induced were observed. Reasons for differences between strains may become more apparent as the mechanism of russet induction is determined. We have demonstrated a good correlation between the ability of isolates to persist epiphytically on fruit and their ability to cause russet. In addition, we previously determined that all A. pullulans and most yeast isolates that cause russet have cutinolytic esterase activity (25). However, the potential role of cutinase in epiphytic survival or russet induction has yet to be demonstrated. Histological studies indicate that russeting of fruit is often initiated with cracks in the fruit cuticle and subsequent death of underlying epidermal cells 

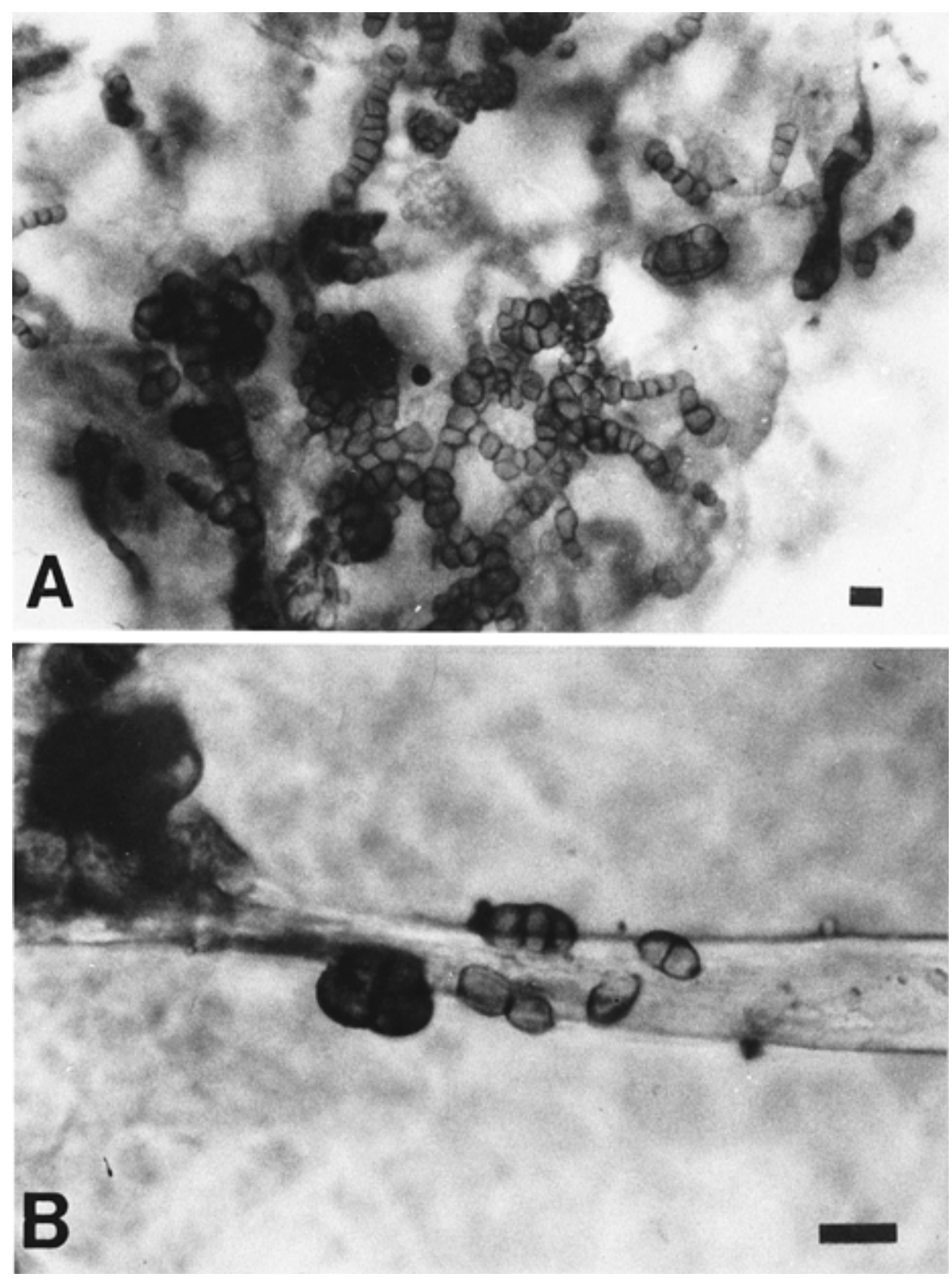

Fig. 3. Sporulation of Aureobasidium pullulans in russeted area of apple cvs. Golden Delicious and McIntosh fruit. (A) Fragmentation of dark hyphae into arthrospores. (B) Arthrospores adhering to fruit hairs. Bar $=10 \mu \mathrm{m}$.

$(1,3,29)$. Cutinase may facilitate epiphytic survival and russet by disrupting the fruit cuticle directly causing russet or exposing the epidermal layer to other factors that cause cell death. Another factor related to fruit russet may be production of IAA, since it is known that some strains of $P$. syringae pv. syringae that produce IAA induce a russet of pear $(6,22)$. A. pullulans and some yeasts have been reported to produce IAA (33). A. pullulans has also been reported to produce phytotoxins (31) that may be responsible for the death of epidermal cells. These and other factors are being explored in relation to the mechanism of fruit russet by $A$. pullulans and epiphytic yeasts.

\section{ACKNOWLEDGMENTS}

We thank C. K. J. Wang for assistance in identifying A. pullulans isolates, J. H. Andrews for fungal isolates, and Judith Burr, Iris Velázquez,
Charles Smith, and Gregg Heidenreich for technical assistance. This research was partially funded by USDA, International Apple Institute.

\section{LITERATURE CITED}

1. Ashizawa, M., Horigome, Y., and Chujo, T. 1984. Histological studies on the cause of russet in Golden Delicious apple. Kagawa Daigaku Nogaku Gakujutsu Hokoku Tech.

2. Barnett, J. A., Payne, R. W., and Yarrow, D. 1990. Yeasts Characteristics and Identification. 2nd ed. Cambridge University, Cambridge.

3. Bell, H. P. 1937. The origin of russeting in the Golden Delicious apple. Can. J. Res. 15:560-566.

4. Burr, T. J., Matteson, M. C., and Corral-Garcia, M. R. 1995. Russet of apple is caused by yeasts that commonly survive in orchards. N.Y. Fruit Quart. 3:7-8 Corral Garcia, M. R., and Huang, T. C. 1996. Effectiveness of bacteria and yeasts from apple orchards as biological control agents of Bull. Fac. Agric. Kagawa Univ. 35:89-99.

5. Burr, T. J., Matteson, M. C., Smith, C. A., apple scab. Biol. Control 6:151-157.

6. Clark, E., and Lindow, S. E. 1989. Indoleacetic acid production by epiphytic bacteria associated with pear fruit russetting. (Abstr.) Phytopathology 79:1191.

7. Cooke, W. B. 1959. An ecological life history of Aureobasidium pullulans (de Bary) $\mathrm{Ar}-$ naud. Mycopathol. Mycol. Appl. 12:1-45.

8. Creasy, L. L. 1980. The correlation of weather parameters with russet of 'Golden Delicious' apples under orchard conditions. J. Am. Soc. Hortic. Sci. 105:735-738.

9. Creasy, L. L. and Swartz, H. J. 1981. Agents influencing russet on 'Golden Delicious' apple fruits. J. Am. Soc. Hortic. Sci. 106:203206.

10. Cummins, J. N., Forsline, P. L., and Way, R. D. 1977. A comparison of russeting among 'Golden Delicious' subclones. HortScience 12:241-242.

11. Easterbrook, M. A., and Fuller, M. M. 1986. Russeting of apples caused by apple rust mite Aculus schlechtendali Acarina Eriophyidae. Ann. Appl. Biol. 109:1-10.

12. Edgerton, L. J., Veinbrants, N., and Hutchinson, J. F. 1976. Foliar sprays of silicon dioxide-containing compound reduce russeting in 'Golden Delicious' apple fruits. HortScience 11:508-509.

13. Faust, M., and Shear, C. B. 1972. Russeting of apples, an interpretive review. HortScience 7:233-235.

14. Foulk, D. S., and Hoover, E. E. 1994. Wax platelet arrangement, GA-4+7 applications, and their relationships to russet in 'Haralson' apples. HortScience 29:472.

15. Greene, D. W. 1993. Effects of GA4 and GA7 on flower bud formation and russet development on apple. J. Hortic. Sci. 68:171-176.

16. Hermanides-Nijhof, E. J. 1977. Aureobasidium and Related Genera in: The Black Yeast and Allied Hyphomycetes. G. S. De Hoog and E. J. Hermanides-Nijhof, eds. Studies Mycol. 15:141-181.

17. Jensen, M. A., Webster, J. A., and Straus, N. 1993. Rapid identification of bacteria on the basis of polymerase chain reaction amplified ribosomal DNA spacer polymorphism. Appl. Environ. Microbiol. 4:945-952.

18. Kinkel, L, L, Andrews, J. H, and Nordheim, E. V. 1989. Fungal immigration dynamics and community development on apple leaves. $\mathrm{Mi}$ crobiol. Ecol. 18:45-58.

19. Kinkel, L. L., Andrews, J. H., and Nordheim, E. V. 1989. Microbial introductions to apple leaves influences of altered immigration on fungal community dynamics. Microbiol. Ecol. 18:161-174.

20. Kirby, A. H. M., and Bennett, M. 1967. Susceptibility of apple and pear varieties to damage by certain organic fungicides. J. Hortic Sci. 42:117-131.

21. Kreger-van Rij, N. J. W. 1984. The Yeasts: A Taxonomic Study. 3rd revised and enlarged ed. Elsevier Science Publishers B. V., Amsterdam.

22. Lindow, S. E. 1987. Severity of pear fruit russetting associated with epiphytic indoleacetic acid-producing bacteria. (Abstr.) Phytopathology 77:1724.

23. Lindow, S. E. 1992. Integrated control of frost injury, fire blight, and fruit russet of pear with a blossom application of an antagonistic bacterium. (Abstr.) Phytopathology 82:1129.

24. Looney, N. E., Granger, R. L., Chu, C. L. McArtney, S. J., Mander, L. N., and Pharis, R. P. 1992. Influences of gibberellins a-4 gibberellin a-4 plus gibberellin a-7 and gibberellin a-4 plus Iso minus gibberellin a-7 on apple fruit quality and tree productivity. I. Effects on fruit russet and tree yield components. J. Hortic. Sci. 67:613-618.

25. Matteson, M. C., Burr, T. J., Corral-Garcia, 
M. R., Parker, D., and Koeller, W. 1995. Russet of apple fruit induced by isolates of Rhodotorula glutinis and Aureobasidium pullulans. (Abstr.) Phytopathology 85:1558.

26. Meador, D. B. 1977. Reducing russet on 'Golden Delicious' apples with silicon dioxide formulation foliage sprays. HortScience 12:504-505.

27. Michailides, T. J. 1991. Russeting and russet scab of prune, an environmentally induced fruit disorder: Symptomatology, induction, and control. Plant Dis. 75:1114-1123.

28. SAS Institute. 1988. SAS/STAT Users Guide. Release 6.03 ed. SAS Institute, Cary, NC.

29. Skene, D. S., and Greene, D. W. 1982. The development of russet, rough russet and cracks on the fruit of the apple 'Cox's Orange Pippin' during the course of the season. J. Hortic. Sci. 57:165-174.

30. Stiles, W. C., Childers, N. F., Prusik, M. J., and Kom, T. N. 1958. Effects of urea sprays and pesticides on russeting and cracking of Stayman apple. J. Am. Soc. Hortic. Sci.
$74: 25-29$.

31. Ten, L. N., Tepanichenko, N. N., Tyshchenko, A. A., Faiziev, M. M., Mukhamedzhanov, S. Z., and A., A. K. 1987. Melaninogenesis and toxin production in phytopathogenic fungi. Mikrobiol. Zh. (Kiev) 49:36-41.

32. Tukey, L. D. 1959. Observations on the russeting of apples growing in plastic bags. J. Am. Soc. Hortic. Sci. 74:30-39.

33. Tuomi, T., Ilvesoksa, J., Laakso, S., and Rosenqvist, H. 1993. Interaction of abscisic acid and indole-3-acetic acid-producing fungi with Salix leaves. J. Plant Growth Regul. 12:149156.

34. Vigalys, R., and Hester, M. 1990. Rapid genetic identification and mapping of enzymatically amplified ribosomal DNA from several Cryptococcus species. J. Bacteriol. 172:42384246.

35. Walter, T. E. 1967. Russeting and cracking in apples. Pages 83-95 in: A review of world literature. Annu. Rep. E. Malling Res. Stn. 1966.
36. Washington, W. S. 1991. Effect of Bordeaux mixture sprays applied after flowering of fruit finish on apricot. Plant. Prot. Quart. 6:188 189.

37. White, T. J., Bruns, T., Lee, S., and Taylor, J. 1990. Amplification and direct sequencing of fungal ribosomal RNA genes for phylogenetics. Pages 315-322 in: PCR Protocols: A Guide to Methods and Applications. M. A. Innis, D. H. Gelfand, J. Sninsky, and T. J. White, eds. Academic Press, San Diego.

38. Xia, C., and Zhou, P. 1988. Factors influencing the formation of russet on the fruit of 'Golden Delicious' apple. Acta Hortic. Sin. 15:139-142.

39. Yoder, K. S., and Hickey, K. D. 1983. Control of apple powdery mildew in the mid-Atlantic region. Plant Dis. 67:245-248.

40. Zobrist, L. 1962. Apple mildew (Podo sphaera leucotricha) as a cause of russeting apples. Proc. Br. Insect Fungic. Conf., Brighton, 1961. 1:237-238. 